\begin{tabular}{|c|c|c|}
\hline & $\begin{array}{l}\text { ANNALES INSTITUTI SLAVICI } \\
\text { UNIVERSITATIS DEBRECENIENSIS }\end{array}$ & \\
\hline SLAVICA XLVIII & 2019 & DEBRECEN \\
\hline
\end{tabular}

Андрей ЧукурОВ

\title{
ПРЕОДОЛЕВАЯ ТРАВМУ: МИНОРИТАРНЫЕ ХУДОЖЕСТВЕННЫЕ ПРАКТИКИ В КОНТЕКСТЕ НОВОЙ ЧУВСТВЕННОСТИ МЕТАМОДЕРНИЗМА
}

\section{Coping with Trauma: Minority Art Practices in the Context of the New Sensuality of Metamodernism}

\begin{abstract}
The information age has provided new opportunities for the institutionalization and functioning of various subcultural movements including those uniting people by offering them an alternative mental state. The proposed material is analyzed as an example of these associations. The article provides a brief analysis of the historical dynamics of the study of minority art practices and of their role and significance at present. Particular attention is paid to the analysis of Art Brut. Today minority art practices find their new meaning also in the context of the new sensuality of metamodernism, which is based on co-creation. We believe that the discourse of outsider art fosters a tolerant consciousness, raising issues of stigma, norm, deviation and internal liberation.
\end{abstract}

Keywords: Art Brut, minority art practices, Outsider Art, metamodernism, new sensuality

Сегодня мы становимся свидетелями небывалой активизации и выхода на авансцену культурной жизни невероятного множества миноритарных культур. Субкультурные группы и движения в наши дни фактически определяют социокультурную повестку и процесс формирования идентичности. Мы не будем вдаваться в анализ причин данного явления, отметим, лишь переход к liquid democracy, оказавшийся возможным исключительно благодаря информационному обществу. Будучи продуктом информационной культуры, liquid democracy реализуется через сетевой инструментарий, в частности, через специальные интернет-платформы, такие как Liquidfeedback, DemocracyOS, Loomio. Речь идет не только о политике и снижении барьеров для участия в социально-политической жизни - удалённыхоn-line голосованиях или делегировании своего голоса тем или иным активистам. Речь идет о невероятных возможностях, которые предоставляет информационная культура тем миноритариями субкультурным сообществам, которые еще недавно не имели возможности ни находить себе подобных, ни влиять на культурную жизнь, ни оказывать другдругу необходимую помощь, ни, естественно, проходить процесс институциализации.

Одной из важных составляющих этого массового «comingout'a» миноритариев становится движение за нейроразнообразие, которое началось с институциализациисообществааутистов, а сегодня уже вышло далеко за его пределы. Остановимся лишь на одном примере. Это российская общественная организация «Психоактивно», имеющая свой паблик в ведущей социальной сети Рос- 
Преодолевая травму: миноритарные художественные практики...

сии - «ВКонтакте». Позиционируют они себя следующим образом: «Это горизонтальная платформа для психоактивистов и всех тех, кто готов заниматься психо-просвещением в любых допустимых формах»-данный текст размещен в самом пабликеhttps://vk.com/psychoactivno. Деятельность паблика и организации направлена на оказание поддержки и взаимопомощи людям с теми или иными ментальными особенностями и/или альтернативными психическими состояниями. За последние два года «Психоактивно» сделали несколько крупных и весьма заметных шагов в «реальный мир». Так, например, 3 июня 2018 года в Москве прошел Психгорфест: Москва психоактивная. Это мероприятие впервые объединило людей с альтернативными ментальными состояниями, журналистов, художников, активистов. Были организованычтение лекций по психологии и психиатрии, выступления поэтов и писателей, состоялась презентация книги «История безумия» издательства Новое литературное обозрение (НЛО), была проведенапсихо-ярмарка и public-talk. Вновь обратимся к прямой цитате из паблика: «Быть психоактивным - не боятся быть собой и говорить о своем состоянии. Быть психоактивным - не скрывать свой диагноз и объединяться с такими же, как ты. Быть психоактивным - выходить из изоляции и самостоятельно создавать пространства для интеграции. Быть психоактивным - искать свое место в городской культуре. Мы - начинаем этот поиск и приглашаем присоединиться к нему всех горожан». Для России, где социальная активность, не укладывающаяся в прокрустово ложе официальных псевдоконсервативных норм и придуманных традиций, если и не является в прямом смысле слова рискованной, то уж мало одобряемой точно, это мероприятие оказалось колоссальным прорывом для данной конкретной миноритарной субкультуры. А ведь еще за месяц до Психгорфеста, 1 мая 2018 года, представителей движения Психоактивно в Санкт-Петербурге, повершивших заверениям властей, что первомайская демонстрация «для всех», задерживала полиция, хотя никаких политических лозунгов в руках у этих людей не было. Причем, от полиции можно было услышать такие фразы: «Здесь люди пришли хорошо провести время, а вы тут со своими психическими проблемами». Однако, мыпомним, что «Миноритарное всегда политично - в том смысле, что частные аберрации, отклонения и вариации приобретают эстетическое и этическое измерение, становятся преодолением границы, познанием и принятием опыта нового, чуждого и другого, обнажением скрытого и подавленного мажоритарной культурой» [ВолодинА 2015]. Вышеозначенный тезис А. Володина использовала для характеристики художественного направления Арт брют, но с нашей точки зрения он может быть транслирован на любую социокультурную деятельность миноритариев.

После этого мероприятия прошли десятки других, количество подписчиков группы в социальной сети заметно выросло. Теперь в рамках этого объединения встречи с творческими людьми, семинары и просмотры фильмов с их дальнейшим обсуждением проходят регулярно. И вот прошел год, и 1 мая 2019 года движение Психоактивно уже полноценно и без проблем было представлено на праздничной демонстрации - никаких задержаний, никаких нелепых 
комментариев со стороны полиции. Признаться, автор этого материала очень переживал за то, как все пройдет, но, - и это самая настоящая победа! - представители движения со своими плакатами спокойно шли в одной колонне с веганами, феминистскими организациями, анархистами и представителями ЛГБТ сообщества. Кстати, для всех этих движений была сформирована своя самостоятельная колонна под номером три. Такая колоннаминоритариев.

В данном контексте новое звучание получает и художественная деятельность людей с альтернативными психическими состояниями. В частности, речь о новом прочтении искусства Арт брют или аутсайдер-арт. Уникальность творческого метода Арт брют заключается прежде всего в том, что данный художественный текст не является репрезентацией реального мира или неких идей и концепций. Произведения Арт брют не имеют внутренних логических связей и не могут оцениваться в категориях академической художественной «нормы». В истории искусства давно и прочно закрепилось словосочетание «примитивное искусство», но даже этот термин категорически не применим к продуктам творчества людей с альтернативными психическими состояниями. Художественный текст Арт брют не является неким творческим экспериментом или, даже, поиском; он не может быть классифицирован или типологизирован. Арт брют - это субъективный и уникальный опыт амбивалентной коммуникации с миром и собой. Немного исторического экскурса. Если говорить в целом о художественном творчестве людей с альтернативной ментальностью, то вряд ли нам удастся выявить его исторические корни, но что до рождения самого термина и первой попытке анализа феномена, то здесь все несколько проще: в 1922 году в свет выходит монография Ханса Принцхорна «Bildnerei der Geisteskranken» («Художественное творчество психически больного»). Работа основана на большом количестве материалов, накопленных и проанализированных X. Принцхорном за годы его медицинской практики. Автор рассматривал наиболее показательный вид творчества -живопись и графику пациентов. До него подобной деятельностью - коллекционированием рисунков пациентов с психическими расстройствами - занимался Эмиль Креплин, благодаря которому сегодня мы имеем концепцию «раннего слабоумия», классификацию неврозов и анализ маниакально-депрессивного психоза. Именно эти люди создали весьма богатую коллекцию картин душевнобольных при Гейдельсбергском университете. Достоянием общественности эти коллекции становятся с 1950 года, когда был проведен Первый Всемирный конгресс по психиатрии и выставлены работы Арт брют. Благодаря материалам, представленным на Конгрессе, и происходит актуализация изучения творческой деятельности людей с альтернативными психическими состояниями.

Необходимо отметить, что сам термин "Арт брют" вводит французский художник Жан Дюбюффе в 1945 г. Этим термином он обозначил собранную им коллекцию, сегодня представленную в Chateau de Beaulieu, в Лозанне (Швейцария). Важной вехой этого процесса институциализации изучения творчества людей с альтернативными психическими состояниями становится 1959 г., когда было создано «Международное общество психопатологии экспрессии» 
Преодолевая травму: миноритарные художественные практики...

(SIPE). В рамках этого Общества происходит объединение разрозненных и во многом интуитивных научных поисков.

В 1972 году теоретик искусства Роджер Кардинал вводит дополнительный термин - «Аутсайдер арт», который в первые годы выступал своеобразным синонимом Арт брют. Однако впоследствии разница все же проявилась - Аутсайдер арт включил также работы художников, не обладающих профессиональной подготовкой, но необязательно являющихся носителями альтернативных психических состояний. В работе «Outsider Art and the autistic creator» [CARDINAL 2009] Роджер Кардинал писал о гибкости критериев для Outsider Art. По его мнению, создателями подобных художественных объектов могут быть люди не только с теми или иными психическими состояниями, но и те, кто не желает функционировать в академической художественной среде, предъявляющей определенные стандарты качества к художественному продукту. С данным мнением согласны далеко не все. Оппоненты Р. Кардинала настаивают на том, что к искусству аутсайдеров можно относить лишь тех, чей разум не попадает в границы общепринятой на данном историческом этапе нормы. Сегодня миноритарное искусство широко представлено в музейных пространствах мира - от Ирландского музея современного искусства до Музея творчества аутсайдеров в Москве.

Если продолжить тему исторической динамики феномена миноритарных художественных практик, то нельзя не упомянуть 1970 - 1980-е гг., когда поднялась самая настоящая волна критики классической психиатрии. Тогда под сомнение была поставлена валидность диагнозов и методов работы психиатров. Сегодня эту критику никто не отменял. Более того, даже в рамках этого, социокультурного дискурса, мы говорим об альтернативных психических состояниях, а не о диагнозах. Политика и стратегия толерантности постепенно вытесняет термин «психически больной». Мы ведем речь об ином видении реальности, что находит отражение в целой галерее художественных образов и текстов: «Меня зовут Кхан», «Форест Гамп», «Таинственная история Билли Миллигана», «Необыкновенное путешествие в безумие и обратно», «Завтра я всегда бывала львом» и т.д. и т.п. В наши дни эта альтернативность восприятия укореняется благодаря движению нейроразнообразия.

Сегодня миноритарные художественные практики обретают новое звучание также в контексте новой чувственности метамодернизма. Не случайно пятым пунктом Манифеста метамодернизма идет следующий тезис: «Все явления находятся в процессе необратимого сползания к состоянию максимального энтропийного несходства. Художественное произведение возможно благодаря рождению или открытию этого различия. Кульминацией его воздействия является непосредственное ощущение различия в самом себе. Роль искусства являет собой исследование возможных результатов его парадоксальных амбиций, подталкивая лишнее к насущному» [ТЁРНЕР 2011].

Основополагающей сущностной характеристикой метамодернизма является синергия. По мысли теоретиков метамодернизма, новая чувственность ба- 
зируется на сотворчестве, коммуникации между человеком и человеком, человеком и Истиной, человеком и миром. Если речь о произведении искусства то, соответственно, это коммуникация человека и текста. Специфика этой коммуникации определяется так называемыми «атмосферами»- термином, введенным Гернотом Бёме. «Атмосферы» - это переживание, которое становится реальностью для субъекта и объекта. Суть творческой деятельности заключается в производстве «атмосфер», наполненных субъективными переживаниями и не существующих для тех, кто находится вне данного пространства. Метамодернистская новая чувственность - это чувственность колебаний между иронией и искренностью, отстранённостью и приверженностью. «Движение должно осуществляться посредством колебания между позициями с диаметрально противоположными идеями, подобно пульсирующим полярностям огромной электрической машины, приводя мир в действие» [ТЁРНЕР 2011]. Именно с таких позиций Арт брют выглядит совершенно иначе, а не просто как «творчество душевнобольных». Миноритарные художественные практики, в том числе все тот же Арт брют, присутствуют в пространстве вполне привычного искусства, но при этом не вполне в него вписывается в силу невозможности его классификации или разработки морфологии. Художественная критика не имеет инструментария для оценки подобного искусства, что вполне объяснимо: Арт брют лишен традиционных смыслов и структуры. Привычные механизмы рецепции для него так же не работают. Он может быть воспринят именно посредством «атмосфер» новой чувственности (напомним, что «атмосфера» по Г. Бёме, это переживание до осмысления), т.е. мы говорим об эмоциональном восприятии явления, без аналитики и логики, с пониманием того, что перед нами способ существования. И это не попытка саморепрезентации и не проявление самосознания как, предположительно, в случае отпечатков ладони первобытного человека на стене пещеры, - ибо в акте творчества Арт брют нет осознанности. Можно с полным правом утверждать, что сегодня, в ситуации метамодернистской новой чувственности, когда рецепция базируется на сотворчестве (синергии) и носит чувственно-эмоциональный характер, Артбрют оказывается на авансцене художественной жизни.

Мы уже обращались к тексту А. Володиной и снова процитируем ее работу: "невозможность выработать внутрихудожественные критерии и специфику, которая отделяла бы их от не-аутсайдеров, и является их специфическим отличительным качеством" [ВолОдиНА 2015]. Речь о том, что любая попытка выделения формальных характеристик выводит нас в психиатрический дискурс. Однако, если мы рассматриваем миноритарные художественные практики с позиций новой чувственности метамодернизма, то все встает на свои места: тезис о колебании с одной стороны и генерации «атмосфер» на фундаменте новой чувственности и искренности с другой, позволяют нам уйти от строгой классификации и медицинской проблематики.

При этом в различных миноритарных арт-практиках, замешанных на альтернативных психических состояниях есть то, что их безусловно объединяет. Прежде всего, это уже указанная коммуникация «автора» и мира: тот же Арт 
Преодолевая травму: миноритарные художественные практики...

брют - это прежде всего взаимодействие. Кроме того, здесь нет стремления к результату. Иными словами, художник не движется по пути к выставке, биеннале, продаже и т.д. - он находится в ситуации проживания образа и цвета. Мы говорим о первостепенном значении процесса. Впрочем, результат, «завершенность» были поставлены под сомнение еще в эпоху постмодерна, а сегодня, в ситуации новой чувственности и вовсе утрачивают свое значение.

Что мы таким образом видим сегодня? Новая чувственность метамодернизма и возможности информационного общества не просто открыли миноритарным художественным практикам двери в некое мейнстримное искусство. Нет, они размыли границы между миноритарным и мейнстримным. Движение по пути метамодернистской энтропии исключает мейнстримность как таковую, уравнивая в правах абсолютно все. И что важнее, делигитимизирует медицинско-психиатрический дискурс. Мы вступаем в эпоху диктатуры миноритариев, когда со сцены не просто уходят «фордистские массы», но нет больше самой «культуры большинства». Это своего рода «очистительный» этап истории культуры, когда происходит освобождение через примирение, через преодоление травмы модернизма, когда «психически здоровое», гетеронормативное и традиционное большинство привело мир к двум мировым войнам, показав свою полную несостоятельность.

Сегодня субкультуры людей с альтернативными физическими и психическими состояниями становятся предметом серьезного анализа со стороны властных структур, поскольку толерантность - объективная характеристика постиндустриального информационного общества. В частности, в России активно развивается инклюзивное образование, которое в Федеральном законе от 29.12.2012 273-Ф3 «Об образовании в Российской Федерации» определяется как «обеспечение равного доступа к образованию для всех обучающихся с учетом разнообразия особых образовательных потребностей и индивидуальных возможностей». Однако, инклюзия - феномен, который следует рассматривать в более широком, чем образовательный, аспекте. Так, в частности, порой в своем стремлении создать «особые» условия для максимально полной самореализации людей с ограниченными возможностями, мы идем по пути «двойной стигматизации»: сначала определяем их как инвалидов (вербально, документально, институционально), а потом создаем эти «особые» условия и нормы, всячески подчеркивая специфический статус этих людей. Это хорошо видно в области художественного творчества, когда дефицит возможностей подменяет собственно эстетические достоинства произведения. К художнику, певцу или спортсмену-инвалиду не предъявляется тех же требований, что и к человеку, не испытывающему, на первый взгляд, дефицит возможностей. В каких-то случаях это справедливо, в иных же напоминает квотирование женщин-депутатов в североевропейских парламентах. Но что уж точно выходит за границы этики, так это зарабатывание денег кураторами и владельцами артгалерей на Арт брют или "disabilityart", когда в рекламе выставки делается акцент на том, что данное произведение искусства создано человеком с ограниченными возможностями [см. подробнее ЧукурОв 2018]. 


\section{Выводы}

Последовательно внедряемый принцип инклюзивности должен преодолеть эти перекосы, превратив альтернативные физические и психические состояния в позитивную культурную идентичность. Так, в частности, в течении 2018 2019 годов все работники сферы образования в России (от дошкольного образования до университетов), как и автор этих строк, в обязательном порядке прошли обучение на курсах повышения квалификации по тематике инклюзивного образования. Примечательно, что, развивая и применяя на практике идеи инклюзии, современное общество возвращается к своим корням: на более ранних стадиях развития того же европейского общества, альтернативные модели поведения и психического состояния вовсе не были стигматизированы. Нередко подобные люди становились пророками, оракулами, посредниками в контактах с иными мирами и т.д., что прекрасно представлено в разнообразных художественных текстах.

Если же говорить конкретно об искусстве Арт брют или иных подобных миноритарных художественных практиках, то необходимо обратить внимание не только на специфику сугубо художественной стороны явления или коммуникативную ее сущность, но также и на весьма важный педагогический аспект явления. В художественном тексте Арт брют переплетаются этика и эстетика. Если с эстетикой все понятно - речь, в конце концов об искусстве, - то с этикой все обстоит сложнее. Дискурс Арт брют или шире, - всего искусства аутсайдеров, - воспитывает толерантное сознание, поднимая вопросы стигматизации, нормы и девиации, искусственности традиций, внутреннего освобождения. Миноритарные художественные практики, в конце концов, формируют новые коммуникативные стратегии и новые идентичности.

\section{Библиография:}

ТЁРнЕР 2011: Тёрнер, Люк, Метамодернист // Манифест //Метамодерн. Журнал о метамодернизме. Режим доступа: http://metamodernizm.ru/manifesto (24.08.2019) свободный.

ЧукурОВ 2018: Чукуров, А. Ю. Культура инвалидности в контексте социокультурной динамики миноритарных групп конца XX - нач. XXI в. // №25 Кривич Н.А. (ред.) Гуманитарное знание: сборник научных статей. Серия «Гуманитарные горизонты»Санкт-Петербург: «Астерион», 20-26.

CARDInal 2009: Cardinal, Roger. Outsider Art and the autistic creator // Philosophical Transactions. R. Soc. B., 1459-1466.

ВолодинА 2015: Володина, А. Аутсайдер-арт как artmineur. // Syg.ma. Режим доступа: https://syg.ma/@alieksandra-volodina/autsaidier-art-kak-art-mineur (07.03.2017) свободный.

Андрей ЧукУРОВ

Российский Государственный Педагогический Университет им. А.И. Герцена

Санкт-Петербург, Россия achukurov@yandex.ru 